\title{
The Influence of Product Quality, Brand Image and Prices on the Purchase Decision of Gudang Garam Cigarettes (Case Study on Gudang Garam Cigarette Consumers in Surabaya)
}

\author{
Denis Fidita Karya ${ }^{1}$, Rachma Rizqina Mardhotillah², Muhammad Muhdhor ${ }^{3}$ \\ Fakultas Ekonomi dan Bisnis \\ Universitas Nahdlatul Ulama Surabaya \\ Surabaya, Indonesia \\ e-mail denisfk@unusa.ac.id
}

\begin{abstract}
This study aims to examine theeffect of the effect of product quality, brand image and price on the purchasing decision of Surya Gudang Garam on Surya Gudang Garam cigarette consumers in Surabaya. The study population was the consumer of Surya Gudang Garam cigarettes in the city of Surabaya. The sampling technique used in this study is probability sampling. This study uses multiple regression analysis with panel data as a data processing tool using the SPSS 25 software program. The results found that product quality has a negative and insignificant effect on purchasing decisions, while price has a positive and significant effect on purchasing decisions, and brand image. positive and significant effect on purchasing decisions.
\end{abstract}

Keywords: Product Quality, Price, Brand Image, Purchase Decision.

\section{INTRODUCTION}

In the modern era like today, smoking is one of the factors that influence people's main lifestyle. Cigarettes have penetrated all levels of society, rich or poor, old or young, from adults to the younger generation and students. The cigarette business is actually created only for adults who choose to smoke or not, but in reality, cigarettes are not only popular with adults but also teenagers and even children. The ease with which cigarettes are found allows these teenagers to quickly become dependent on cigarettes, and they will like cigarettes even more. Every place sells cigarettes from various brands, from the cheapest to the most expensive. Riskesdas 2018 data shows the number of smokers over 15 years of $33.8 \%$. Of these $62.9 \%$ are male and $4.8 \%$ are female smokers. Based on data from the 2018 National Basic Health Research (Riskesdas), the prevalence of smoking in adolescents aged 10 years to 18 years has increased by $1.9 \%$. This percentage figure far exceeds the upper limit set by the 2019 RPJMN of 5.4\%. Indonesia has 2.5 million outlets that are retailers of cigarettes. This figure does not take into account the cigarette-selling kiosks on the side of theroad. 


\section{Procedia Business and Financial Technology}

Proceedings of the 2nd International Conference on Business and M anagement of T echnology (ICO N BM T 2020) - Part 2

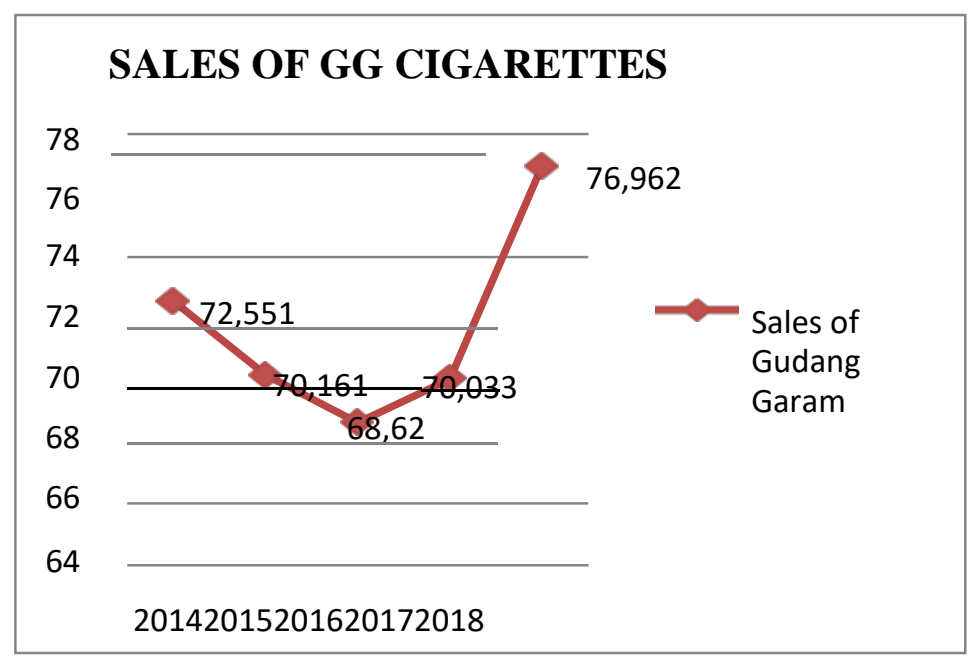

source: PT. Gudang Garam Website

One of the products of PT Gudang Garam Tbk that has become a mainstay and has been accepted by the public is Surya Gudang Garam. The Gudang Garam solar cigarette is part of the surya family, the surya family is divided into four products, namely Surya Gudang Garam which is claimed by this company as brand no. 1 in Indonesia in the SKM Full Flavor category. This filter cigarette brand is available in three packs, namely 12 and 16 sticks for regular packs and 50 sticks for cans. In the picture above shows the sales of SKM Gudang Garam solar cigarettes in 2014 decreased until 2016 and experienced an increase in the following years, namely in 2017 and 2018, in 2017 with total sales of 70,033 sticks and in 2018 with total sales of 76,962 .

The increase in tobacco excise on average reaches 21.55 percent in 2020 by theMinister of Finance Sri Mulyani Indrawati which is regulated in the Minister of Finance Regulation (PMK) Number 152 / PMK.010 / 2109. The regulation regulates that the largest increase in cigarette excise rates is on Machine White Cigarettes (SPM), which is 29.96 percent. The excise on hand-filtered cigarettes (SKTF) increased by 25.42 percent, machinemade cigarettes (SKM) 23.49 percent, and hand-rolled cigarettes (SKT) 12.84 percent.

There is a fairly tight industrial competition between the products of PT Gudang Garam Tbk and PT Sampoerna which have flagship products, a brand image that is well known to the public and the phenomenon of price increases that have been decided by the minister of finance so this research is made to determine whether product competition, image brand and price influence the sales levels of these large companies.

\section{RESEARCH METHODOLOGY}

The population in this study were cigarette consumers, especially Surabaya students. In this study, the number of samples was 75 people who came from consumers of the Gudang garam solar cigarette. So, with the number of indicators as much as 15 multiplied by 5 . So, through calculations based on this formula, the number of samples from this study is 75 people who come from solar cigarette consumers Gudang Salt. The sampling technique used in this study is probability sampling.

Based on several criteria, namely: Consumers who consume Surya Gudang Garam cigarettes for $\leq 1$ year. Second, consumers who are 17 years of age and over because they are considered able to provide an objective opinion.

The data analysis used includes descriptive statistics, classical assumption test, multiple linear regression and hypothesis testing. All tests in this researcher used SPSS 25. for windows software.

The Hypotheses in this research are:

H1: Product quality has a positive and significant effect on the Purchasing Decision variable.

$\mathrm{H} 2$ : Brand Image has a positive and significant effect on the Purchasing Decision variable.

H3: Price has a positive and significant effect on the Purchasing Decision variable.

\section{RESULT AND ANALYSIS}

\section{a. Effect of Product Quality on Purchasing Decisions}

From the results of the $t$ test on the product quality variable, it shows that the product quality is not significant to the purchase decision, thus it is stated that the product quality variable does not affect the purchasing decision of Gudang garamsolar cigarettes.

$\mathrm{Ho}=\mathrm{H} 1=0$ (product quality has no effect on purchasing decisions) accepted and $\mathrm{Ha}=\mathrm{H} 1 \mathrm{C} \mathrm{O}$ (Product quality affects the purchasing decision) rejected. 


\section{Procedia Business and Financial Technology}

Proceedings of the 2nd International Conference on Business and M anagement of T echnology (ICO N BM T 2020) - Part 2

\section{b. The Influence of Brand Image on Purchasing Decisions}

From the results of the $t$ test on the brand image variable shows a positive and significant result on purchasing decisions on the solar cigarette at Gudang garam in Surabaya, thus the hypothesis which states that the brand image variable has a significant effect on purchasing decisions.

$\mathrm{Ho}=\mathrm{H} 2=\mathrm{O}$ (Brand image has no effect on purchasing decisions) is rejected and $\mathrm{Ha}=\mathrm{H} 2$ Ç 0 (Brand image has no effect on purchasing decisions) is accepted.

This study supports the results of previous research conducted [1] that brand image has a significant effect on purchasing decisions on Sampoerna A mild cigarettes in Kediri.

\section{c. Effect of Price on Purchasing Decisions}

From the results of the $t$ test on the price variable, it shows a positive and significant result on the purchase decision on the solar cigarette at Gudang garam in Surabaya, thus the hypothesis that the price variable has a significant effect on the purchase decision. $\mathrm{Ho}=\mathrm{H} 3=0$ (Price has no effect on purchasing decisions) is rejected and $\mathrm{Ha}=\mathrm{H} 3$ Ç 0 (Price affects purchasing decisions) is accepted.

This study supports the results of previous research conducted [1] that price has a significant effect on purchasing decisions on Sampoerna A mild cigarettes in Kediri. Although there are differences from previous research conducted by Jilly Bernadette Mandey [2] Price does not have a significant effect on purchasing decisions.
Based on the results of data analysis and the discussion that has been described, the following conclusions can be drawn:

1. Based on the results of the first statistical analysis shows that the product quality variable partially has a negative and insignificant effect on the Purchasing Decision variable for Surya Gudang Garam cigarette consumers in Surabaya.

2. Based on the results of the second statistical analysis shows that the price variable partially has a significant positive effect on the Purchasing Decision variable for the Surya Gudang Garam cigarette consumer in Surabaya.

3. Based on the results of the third statistical analysis shows that the brand image variable partially has a significant positive effect on the Purchasing Decision variable for the consumer of Surya Gudang Garam cigarettes in Surabaya.

\section{REFERENCES}

[1] C. J. Gerung, J. Sepang, and S. Loindong, Pengaruh Kualitas Produk, Harga dan Promosi Terhadap Keputusan Pembelian Mobil Nissan X-Trail Pada $P T$, vol. 5, no. 2. Jurnal EMBA: Wahana Wirawan Manado, 2017.

[2] J. B. Mandey, Promosi, distribusi, harga pengaruhnya terhadap keputusan pembelian Rokok Surya Promild", vol. 1, no. 4. Jurnal EMBA: Jurnal Riset Ekonomi, Manajemen, Bisnis dan Akuntansi, 2013.

\section{CONCLUSION}

